Leszek Jarzębowicz

Politechnika Gdańska

Wydziat Elektrotechniki i Automatyki

\title{
Estymacja położenia wirnika w bezczujnikowym napędzie trakcyjnym z silnikiem IPMSM
}

\begin{abstract}
W referacie omówiono problematykę estymacji położenia katowego wirnika silnika IPMSM w aspekcie zastosowań trakcyjnych. Przedstawiono metody estymacji położenia katowego wirnika silnika IPMSM umożliwiajace stabilna pracę napędu w petnym zakresie prędkości. Omówione algorytmy estymacji położenia opieraja się na analizie wartości pochodnych prąów fazowych silnika zwiqzanych $z$ modulacja napięć realizowanq przez falownik tranzystorowy. Zaproponowane algorytmy odtwarzania wielkości mechanicznych charakteryzuja się nieskomplikowanymi zależnościami matematycznymi wykorzystujacymi wartości pochodnych pradów fazowych silnika. Zaprezentowano wyniki eksperymentalne pracy estymatorów.
\end{abstract}

\section{Wstęp}

W trakcyjnych układach napędowych wzrasta liczba zastosowań silników elektrycznych z wysokoenergetycznymi magnesami trwałymi, a wśród nich silników synchronicznych $\mathrm{z}$ sinusoidalnym rozkładem pola magnetycznego $\mathrm{w}$ szczelinie powietrznej (ang. Permanent Magnet Synchronous Motors, PMSM) [1, $10,12]$. Wynika to z korzystnych cech tego typu silników, tj.: dużej sprawności, dobrych właściwości regulacyjnych, zamkniętej budowy, relatywnie małej masy i objętości oraz łatwo realizowanego chłodzenia.

Stojan silnika PMSM ma budowę podobną do stojana silnika indukcyjnego - w żłobkach rozłożone jest trójpasmowe uzwojenie [3, 10, 14]. Konstrukcja wirnika zawiera magnesy trwałe umieszczone na powierzchni lub wewnattrz rdzenia wirnika. Do napędu pojazdów częściej stosowane są silniki PMSM z magnesami zagłębionymi $\mathrm{w}$ wirniku (ang. Interior PMSM, IPMSM). Silniki takie, w porównaniu do silników z magnesami przyklejonymi na powierzchni wirnika (ang. Surface PMSM, SPMSM), są nieco droższe, lecz mają większą sprawność, szczególnie przy dużych prędkościach kątowych wirnika [2]. Fragment struktury obwodu magnetycznego przykładowego silnika IPMSM przedstawiono na rys. 1.

W algorytmach wektorowego sterowania silnikami PMSM jedną z podstawowych wielkości wejściowych jest kąt położenia osi magnetycznej wirnika względem uzwojeń stojana $[3,8,14]$. Położenie to jest $\mathrm{z}$ reguły wyznaczane przy pomocy przetworników sprzężonych mechanicznie $\mathrm{z}$ osia wirnika - optoelektronicznych przetworników obrotowo-impulsowych (ang. encoders) lub transformatorów położenia kątowego (ang. resolvers). Innym sposobem jest obliczanie po-

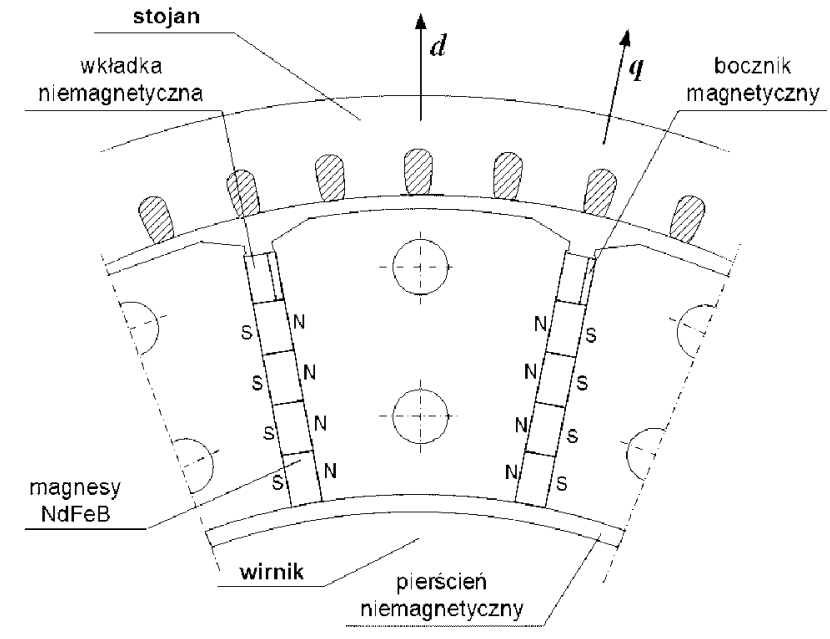

Rys. 1. Fragment struktury obwodu magnetycznego silnika IPMSM typu RTMds26-06 [8]

łożenia wirnika na podstawie pomiarów przebiegów określonych wielkości elektrycznych. Metody sterowania uzupełnione o algorytmy estymacji położenia kątowego wirnika nazywa się metodami bezczujnikowymi (ang. sensorless) [3, 7, 14]. W napędach małych mocy rezygnacja $\mathrm{z}$ przetwornika wielkości mechanicznych zmniejsza koszt realizacji i rozmiar układu. Wykorzystanie metod bezczujnikowych jest także uzasadnione w przypadku napędów wykorzystujących silniki o specjalnych konstrukcjach, np. silniki przeznaczone do tzw. napędu bezpośredniego, w którym silniki zintegrowane są z kołami pojazdu lub umieszczone bezpośrednio obok nich. W takich rozwiązaniach sprzęgnięcie przetwornika $\mathrm{z}$ wirnikiem silnika jest często zadaniem niełatwym. 


\section{Metody estymacji położenia silnika IPMSM}

Metody odtwarzania położenia kątowego wirników silników PMSM można podzielić na dwie zasadnicze grupy [14]: algorytmiczne i fizykalne. Estymatory z pierwszej grupy bazują na odnajdywaniu kierunku wektora siły elektromotorycznej silnika, czyli wektora napięcia indukowanego $\mathrm{w}$ uzwojeniach stojana na skutek zmiennego pola od magnesów trwałych wirnika. Metody fizykalne zaś pozwalają na odtworzenie położenia wirnika poprzez analizę wartości indukcyjności stojana.

Napędy trakcyjne charakteryzują się specyficznymi warunkami pracy, m.in. należy zapewnić: duży moment rozruchowy - już od prędkości zerowej, szeroki zakres regulacji prędkości i momentu z możliwością przeciążania silnika. Napęd musi realizować hamowanie odzyskowe. Występują duże zmiany napięcia zasilającego.

Metodom sterowania napędów trakcyjnych stawia się zatem wysokie wymagania, szczególnie trudne do spełnienia w układach bezczujnikowych. Specyficzne wymagania skłaniaja do wykorzystywania $\mathrm{w}$ napedach pojazdów łączonych metod estymacji, z estymatorami fizykalnymi i algorytmicznym [12]. Komplikuje to realizację trakcyjnego układu bezczujnikowego.

\subsection{Metody algorytmiczne}

Wyznaczenie składowych wektora siły elektromotorycznej zazwyczaj nie wymaga ingerencji w sposób sterowania falownikiem tranzystorowym. Pomiar siły elektromotorycznej odbywa się $\mathrm{z}$ reguły w sposób pośredni, poprzez analizę przebiegów prądów silnika $[3,4]$.

Algorytmiczna metoda estymacji pozwala na dokładne odtwarzanie położenia wirnika tylko w zakresie średnich i dużych prędkości kątowych wirnika. Przy małych prędkościach siła elektromotoryczna silnika jest niewielka, więc jej wpływ na mierzone prądy jest trudny do wyodrębnienia. Określenie położenia wirnika zatrzymanego za pomocą metod algorytmicznych jest niemożliwe. Ograniczenia te są istotne w zastosowaniach trakcyjnych.

W literaturze spotyka się rozwiązania estymatorów, którym przypisuje się możliwość wykonania rozruchu bez znajomości warunków początkowych. Możliwość ta ogranicza się jednak do układów o małym rozruchowym momencie obciążenia. Ponadto przebieg momentu elektromagnetycznego $\mathrm{W}$ początkowej fazie rozruchu jest niekontrolowany $\mathrm{z}$ uwagi na brak możliwości wyznaczenia położenia przed uzyskaniem dostatecznej prędkości. W napędzie pojazdu, ze względu na specyficzne warunki pracy oraz wymagania, zastosowanie tego typu estymatora jako autonomicznego rozwiązania jest niemożliwe. Do wyjątków zaliczyć można implementację estymatora algorytmicznego w napędzie roweru elektrycznego, w którym silnik trakcyjny pełni jedynie funkcję wspomagająca rowerzystę. W takim rozwiązaniu napęd elektryczny włączany jest po przekroczeniu pewnej prędkości kątowej wirnika.

\subsection{Metody fizykalne}

Estymatory fizykalne wykorzystują, jako źródło informacji o położeniu kątowym wirnika, asymetrię magnetyczną obwodu magnetycznego silnika. W silniku IPMSM asymetria ta jest $\mathrm{z}$ reguły wyraźna i wynika ze struktury wirnika $[2,3,14]$.

Metody fizykalne wymagaja generacji dodatkowej składowej napięcia zasilającego silnik, która pozwala wyznaczyć asymetrię obwodu magnetycznego na podstawie analizy odpowiedzi prądowej silnika. Napięcie to, wytwarzane przez falownik, może być „nałożone" na napięcie zasilające silnikiem lub występować w krótkich przerwach pomiędzy cyklami generacji napięcia zasilającego [14]. Wykorzystuje się częstotliwości z zakresu od kilkuset herców do kilku kiloherców. Stosunkowo duża częstotliwość pozwala pominąć $\mathrm{w}$ obliczeniach rezystancję stojana oraz odseparować składową prądu będącą odpowiedzią silnika na napięcie wymuszające. Zakres częstotliwości napięcia wymuszającego jest jednak ograniczony od góry ze względu na możliwość jego realizacji przez falownik pracujący z określoną częstotliwością modulacji.

Dodatkowy, wymuszający składnik występujący w przebiegu napięcia silnika jest źródłem wielu problemów [14]. Generowane są dodatkowe straty oraz hałas. Przy wyższych prędkościach mogą występować pulsacje momentu. Dodatkowo, w torach regulatorów należy stosować filtry dolnoprzepustowe, co ogranicza dynamikę układu. Sygnalizowane są problemy związane z niedostatecznie częstą aktualizacją wartości wielkości odtwarzanych, która wynika $\mathrm{z}$ częstotliwości napięcia wymuszającego. $Z$ powyższych powodów metody fizykalne stosowane są zazwyczaj tylko przy niewielkich prędkościach kątowych wirnika.

\subsection{Metoda startowa}

Zmiany indukcyjności stojana są funkcją podwojonego elektrycznego kąta położenia wirnika. W związku z powyższym, na podstawie analizy indukcyjności stojana nie można bezpośrednio wyznaczyć biegunowości magnesów wirnika, a jedynie kierunek osi związanej ze strumieniem magnetycznym (kierunek osi $d$ ). Do wyznaczania biegunowości stosuje się metody startowe wykorzystujące zjawisko nasycenia obwodu magnetycznego. Metoda taka jest wywoływana jednokrotnie, po uruchomieniu napędu, aby rozpoznać zwrot wektora pola magnetycznego magnesów [7]. 


\section{Estymatory polożenia oparte na analizie po- chodnych prądów silnika}

Wśród metod odtwarzania położenia kątowego wirnika silnika PMSM, jako szczególną grupę wyróżnić można algorytmy oparte na analizie szybkości zmian prądów fazowych silnika wywołanych modulacją napięcia za pośrednictwem falownika tranzystorowego (ang. current ripples, current derivatives, PWM transients) $[5,6,7,9,11,13]$.

\subsection{Wyznaczanie pochodnych prądów fazowych silnika}

Silniki PMSM odznaczają się małymi wartościami indukcyjności stojana. W konsekwencji pulsacje prądów wywołane modulacją napięcia zasilającego silnik są znaczne (rys. 2).

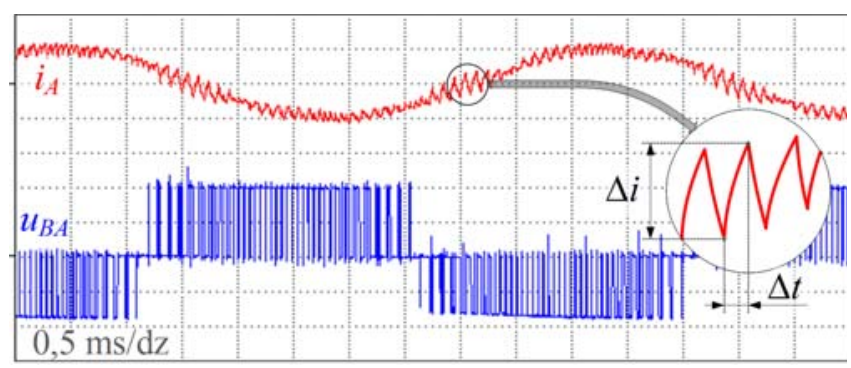

Rys. 2. Oscylogram napięcia przewodowego $u_{B A}(110 \mathrm{~V} / \mathrm{dz}) \mathrm{i}$ prądu fazowego $i_{A}(10 \mathrm{~A} / \mathrm{dz})$ silnika IPMSM zasilanego $\mathrm{z}$ falownika napięcia pracującego z częstotliwością modulacji $f_{\text {mod }} \cong$ $10 \mathrm{kHz}[6]$

Szybkości zmian (pochodne) prądów fazowych wyznaczane są dla wybranych podokresów modulacji napięcia. Zakłada się, że napięcia wyjściowe falownika są stałe w analizowanym czasie, zawierającym się $\mathrm{w}$ podokresie modulacji. Prądy fazowe zmieniają się wykładniczo, ale czas trwania podokresu jest krótki w porównaniu do stałej czasowej obwodu. Pozwala to przyjąć uproszczenie, iż prąd zmienia się liniowo. W związku z tym, aby określić szybkość zmian prądu wystarczą dwie wartości zmierzone w znanym odstępie czasu. Wartość pochodnej jest zatem przybliżona ilorazem różnicowym [6]:

$$
\frac{\mathrm{d} i}{\mathrm{~d} t} \cong \frac{\Delta i}{\Delta t}
$$

\subsection{Wykorzystanie pochodnych prądów silnika do obliczania kąta położenia wirnika}

Równania modelu matematycznego silnika IPMSM w układzie współrzędnych $d q$ związanym z wirnikiem, w którym oś $d$ pokrywa się $\mathrm{z}$ wektorem pola od magnesów trwałych, mają postać [14]:

$$
\begin{gathered}
\frac{\mathrm{d} i_{d}}{\mathrm{~d} t}=\frac{1}{L_{d}}\left(-R_{s} i_{d}+L_{q} p \omega_{m} i_{q}+u_{d}\right), \\
\frac{\mathrm{d} i_{q}}{\mathrm{~d} t}=\frac{1}{L_{q}}\left(-R_{s} i_{q}-L_{d} p \omega_{m} i_{d}-p \omega_{m} \psi_{f}+u_{q}\right),
\end{gathered}
$$

gdzie: $i_{d}, i_{q}, u_{d}, u_{q}, L_{d}, L_{q}$ - odpowiednio: prądy, napięcia i indukcyjności stojana wyrażone $\mathrm{w}$ układzie współrzędnych $d q ; \psi_{f}$ - strumień od magnesów trwałych w wirniku; $R_{s}$ - rezystancja uzwojeń stojana; $\omega_{m}$ - prędkość kątowa wirnika, $p$ - liczba par biegunów.

$\mathrm{Na}$ szybkość zmian prądów fazowych silnika wpływa szereg czynników, tj.: rezystancja i indukcyjność obwodu stojana, siła elektromotoryczna, wartości prądów i napięć stojana silnika oraz prędkość kątowa wirnika. W oparciu o wartości pochodnych prądów można zatem opracować zarówno estymator fizykalny jak i algorytmiczny.

Estymacja położenia poprzez rozwiązanie standardowych równań silnika jest niemożliwa ze względu na zbyt dużą liczbę niewiadomych. Model silnika jest zatem znacznie upraszczany. Ponadto zakłada się, iż parametry mechaniczne, a w szczególności położenie i prędkość wirnika, są wolnozmienne w relacji do elektrycznych.

\subsection{Algorytm matematyczny estymacji położenia wirnika}

Pomiar prądów, na podstawie którego wyznaczane są pochodne, odbywa się $\mathrm{w}$ naturalnym układzie współrzędnych $A B C$. W referacie posłużono się wartościami przetransformowanymi do ortogonalnego układu $\alpha \beta$ (transformacja Clarke [3, 14]), którego oś $\alpha$ pokrywa się z osią $A$. Pozwoliło to uprościć zapis matematyczny.

W celu zapewnienia dokładnych wyników estymacji w całym zakresie prędkości roboczych napędu zaproponowano dwie metody estymacji - fizykalną oraz algorytmiczną. Wybór aktywnej metody uzależniony jest od bieżącej prędkości kątowej wirnika. Jako wartość progową prędkości, przy której następuje przełączenie, dobrano taką, dla której błędy estymacji obu algorytmów są zbliżone. Poza powyższymi algorytmami zaimplementowano także metodę startową $\mathrm{w}$ celu rozpoznania zwrotu wektora pola magnetycznego magnesów. Metodę tą opisano w pracy [7].

Procedura estymacji położenia zaproponowana dla średnich i dużych prędkości wykorzystuje, jako wielkości wejściowe, szybkości zmian prądów silnika $\mathrm{d} i_{\alpha o} / \mathrm{d} t, \mathrm{~d} i_{\beta 0} / \mathrm{d} t$ określone podczas realizacji tzw. wektorów zerowych napięcia na wyjściu falownika $[3,4]$. Odtwarzane położenie kątowe $\theta_{E}$ oblicza się przy pomocy poniższego wzoru: 


$$
\theta_{E}^{*}=\operatorname{arctg}\left(\frac{\mathrm{d} i_{\alpha 0}}{\mathrm{~d} t} /\left(-\frac{\mathrm{d} i_{\beta 0}}{\mathrm{~d} t}\right)\right) .
$$

Wykorzystanie dwuargumentowej funkcji arctg pozwala na jednoznaczne wyznaczenie położenia $\mathrm{w}$ zakresie pełnego obrotu elektrycznego. W realizacji praktycznej opisywana procedura związana jest $\mathrm{z}$ ograniczeniem maksymalnej wartości napięcia wyjściowego falownika (uśrednionego za okres modulacji), ponieważ konieczne jest występowanie podokresów związanych z realizacją wektorów zerowych o czasie trwania wystarczającym do wyznaczenia wielkości wejściowych procedury. Wzór (4) jest poprawny dla dodatnich prędkości kątowych. W przypadku prędkości o przeciwnym znaku należy wynik skorygować o wartość $\pi$. Opisywana procedura przeznaczona jest dla średnich i dużych prędkości kątowych wirnika, znak prędkości jest wtedy jednoznacznie rozpoznany.

Dla małych prędkości kątowych oraz wirnika zatrzymanego położenie kątowe obliczane jest na podstawie szybkości zmian prądu $\mathrm{d} i_{\alpha 1} / \mathrm{d} t, \mathrm{~d} i_{\beta 1} / \mathrm{d} t, \mathrm{~d} i_{\alpha 3} / \mathrm{d} t$, $\mathrm{d} i_{\beta 3} / \mathrm{d} t, \mathrm{~d} i_{\alpha 5} / \mathrm{d} t, \mathrm{~d} i_{\beta 5} / \mathrm{d} t$ wyznaczonych podczas generacji trzech wektorów aktywnych: $\underline{\mathrm{V}}_{1}, \underline{\mathrm{V}}_{3}, \underline{\mathrm{V}}_{5}$, których kierunki i zwroty odpowiadają osiom układu współrzędnych $\mathrm{ABC}[3,4]$. Do obliczeń wykorzystuje się także pochodne $\mathrm{d} i_{\alpha 0} / \mathrm{d} t, \mathrm{~d} i_{\beta 0} / \mathrm{d} t$ wyznaczone podczas realizacji wektora zerowego $\underline{\mathrm{V}}_{0}$. Standardowa metoda modulacji nie zapewnia generacji sekwencji napięciowych pozwalających na pomiar szybkości zmian prądu we wspomnianych warunkach. Należy to zapewnić przez odpowiednią cykliczną modyfikację wartości wejściowych modulatora [7].

Obliczane są wartości $s_{1}, s_{3}, s_{5}$ wyrażające szybkości zmian prądu wywołane trzema niezerowymi wektorami $\underline{\mathrm{V}}_{1}, \underline{\mathrm{V}}_{3}, \underline{\mathrm{V}}_{5}$ napięć stojana:

$$
\begin{aligned}
& s_{1}=\sqrt{\left(\frac{\mathrm{d} i_{\alpha 1}}{\mathrm{~d} t}-\frac{\mathrm{d} i_{\alpha 0}}{\mathrm{~d} t}\right)^{2}+\left(\frac{\mathrm{d} i_{\beta 1}}{\mathrm{~d} t}-\frac{\mathrm{d} i_{\beta 0}}{\mathrm{~d} t}\right)^{2}}, \\
& s_{3}=\sqrt{\left(\frac{\mathrm{d} i_{\alpha 3}}{\mathrm{~d} t}-\frac{\mathrm{d} i_{\alpha 0}}{\mathrm{~d} t}\right)^{2}+\left(\frac{\mathrm{d} i_{\beta 3}}{\mathrm{~d} t}-\frac{\mathrm{d} i_{\beta 0}}{\mathrm{~d} t}\right)^{2}}, \\
& s_{5}=\sqrt{\left(\frac{\mathrm{d} i_{\alpha 5}}{\mathrm{~d} t}-\frac{\mathrm{d} i_{\alpha 0}}{\mathrm{~d} t}\right)^{2}+\left(\frac{\mathrm{d} i_{\beta 5}}{\mathrm{~d} t}-\frac{\mathrm{d} i_{\beta 0}}{\mathrm{~d} t}\right)^{2}} .
\end{aligned}
$$

Następnie wyznaczany jest wektor reprezentujący różnicę w szybkościach zmian prądów odpowiadających wymuszeniom napięciowym opisanym trzema wektorami aktywnymi. Składowe tego wektora obliczane są ze wzorów:

$$
\begin{aligned}
& s_{\alpha}=s_{1}-\left(s_{3}+s_{5}\right) \cdot \sin 30^{\circ}, \\
& s_{\beta}=\left(s_{3}-s_{5}\right) \cdot \sin 60^{\circ} .
\end{aligned}
$$

Położenie kątowe, obejmujące zakresem połowę obrotu elektrycznego, wyznaczane jest jako kierunek odpowiadający najmniejszej szybkości zmian prądu, a więc kierunek prostopadły do wektora $\underline{s}=s_{\alpha}+\mathbf{j} s_{\beta}$ :

$$
2 \theta_{L}^{*}=\operatorname{arctg}\left(s_{\alpha} /\left(-s_{\beta}\right)\right) .
$$

\section{Stanowisko badawcze}

Schemat blokowy stanowiska badawczego przedstawiono na rys. 3. Stanowisko zawiera 18-biegunowy silnik IPMSM typu RTMds26-06 o prototypowej konstrukcji. Wartości znamionowe mocy, momentu i prądu silnika wynoszą odpowiednio: $P_{n} \cong 16 \mathrm{~kW}, T_{n}=$ $45 \mathrm{Nm}, I_{n}=30,5 \mathrm{~A}$. Współczynnik asymetrii magnetycznej jest niewielki, wynosi $L_{q} / L_{d} \cong 1,2$. Obciążenie mechaniczne silnika IPMSM stanowi napęd prądu stałego sterowany za pośrednictwem przekształtnika czterokwadrantowego. Sterownik cyfrowy zbudowano w oparciu o 32-bitowy procesor sygnałowy TMS320F2812 firmy Texas Instruments, taktowany zegarem o częstotliwości $f_{\text {osc }}=120 \mathrm{MHz}$. Procesor dedykowany jest do zastosowań napędowych, zawiera szereg konfigurowalnych modułów sprzętowych.

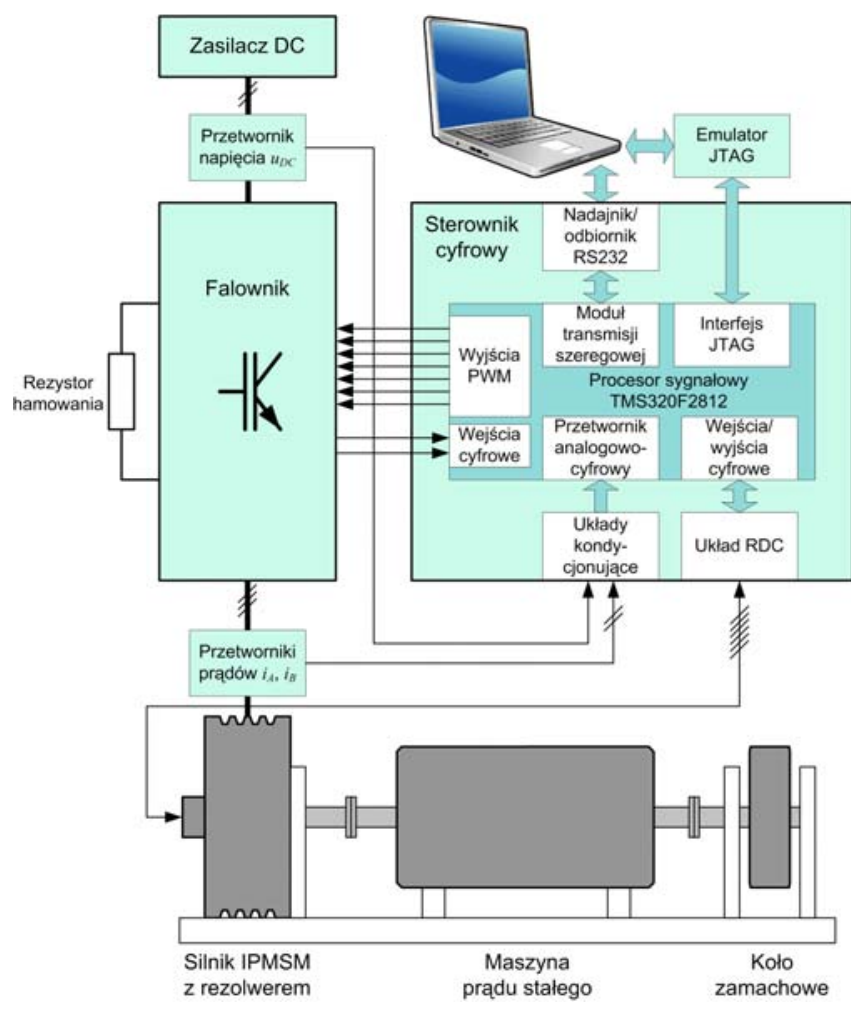

Rys. 3. Schemat blokowy stanowiska badawczego [7]

\section{Przykładowe wyniki badań}

Wybrane wyniki badań zaproponowanych estymatorów przedstawiono na rys. 4. Symbole użyte na wykresach oznaczają: $\omega_{m}, \omega_{m}{ }^{*}-$ prędkość kątowa wirnika (odpowiednio: zmierzona oraz estymowana); $i_{q}, i_{q_{-} r e f}$ - składowa $q$ prądu silnika (odpowiednio: 
a)
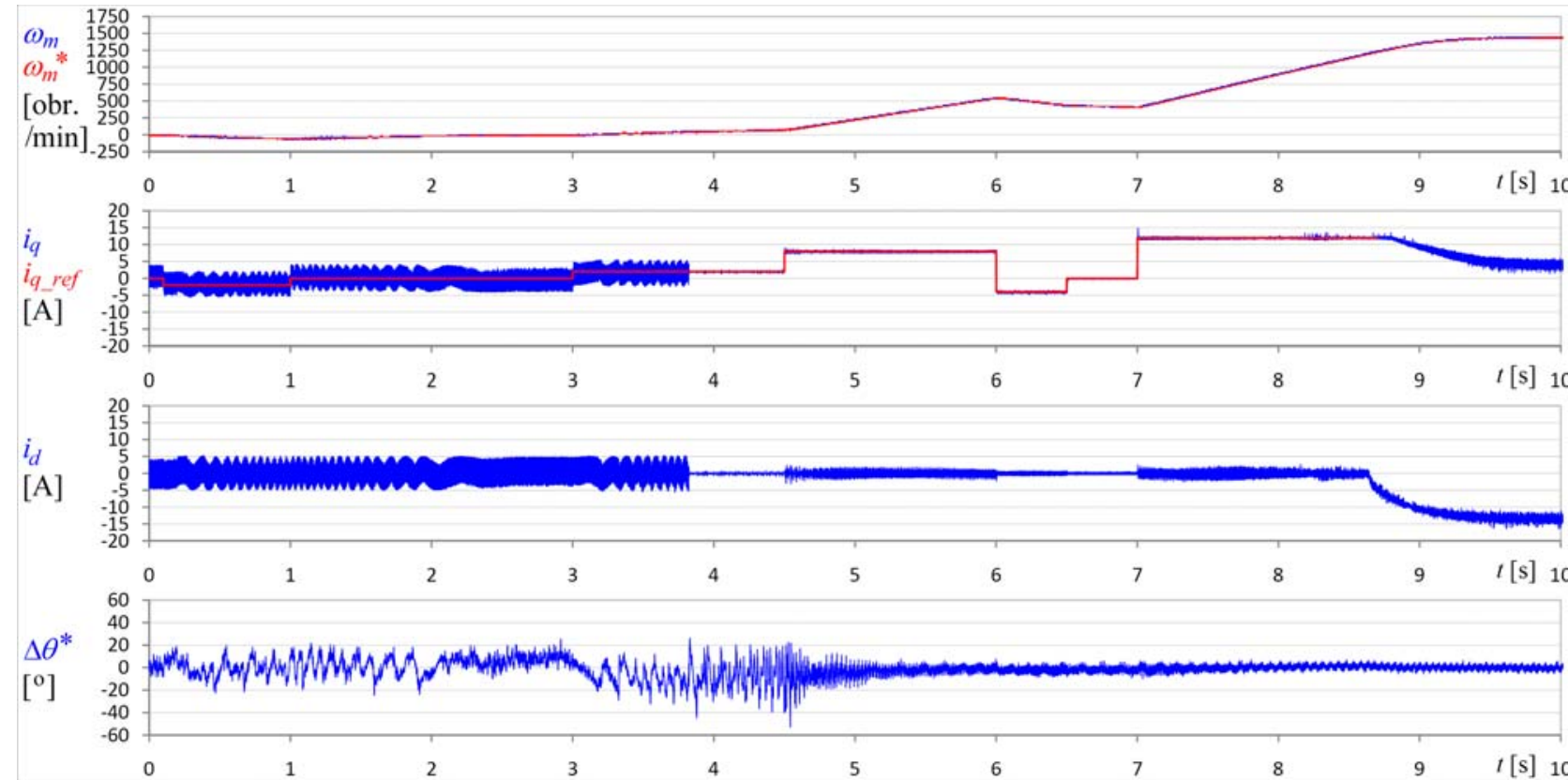

b)
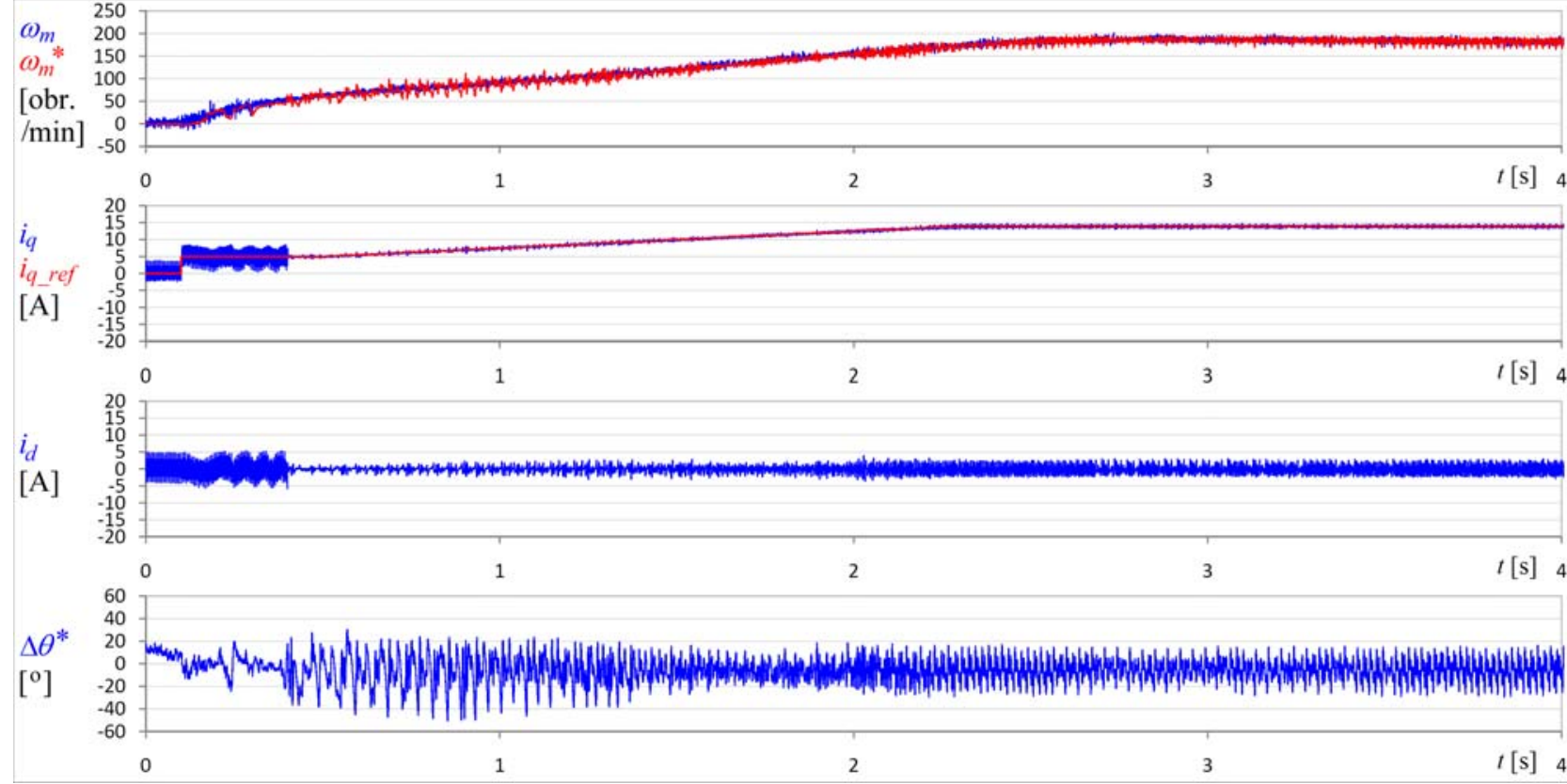

Rys. 4. Przebiegi wielkości elektrycznych i mechanicznych podczas: a) pracy nieobciążonego napędu w dużym zakresie prędkości kątowych, b) rozruchu napędu obciążonego momentem $M_{r} \cong 15 \mathrm{Nm}$

obliczona na podstawie pomiarów oraz zadana); $i_{d}-$ składowa $d$ prądu silnika obliczona na podstawie pomiarów, $\Delta \theta^{*}-$ błąd estymacji położenia kątowego wirnika.

Cykl pracy napędu, którego dotyczy a, zawiera następujące fazy ruchu: rozruch $\mathrm{z}$ małym momentem elektromagnetycznym - wybieg do uzyskania prędkości zerowej - rozruch w przeciwnym kierunku: najpierw $\mathrm{z}$ małym, następnie $\mathrm{z}$ dużym momentem hamowanie - wybieg - rozruch $\mathrm{z}$ dużym momentem, aż do przejścia do strefy sterowania $\mathrm{z}$ osłabianiem strumienia [2, 3]. Prędkość $\omega_{m}{ }^{*}$ obliczana przez analizę zmian wartości odtwarzanego położenia $\theta^{*}$ dobrze odzwierciedla zmienność wielkości $\omega_{m}$ obliczanej przez algorytm czujnikowy. Błędy estymacji położenia mieszczą się w zakresie $\mid$ ? $\theta^{*} \mid<45^{\circ}$ dla prędkości $\left|\omega_{m}\right|<150 \mathrm{obr} . / \mathrm{min}$. Dla wyższych prędkości błąd zawiera się w zakresie $\mid$ ? $\theta^{*} \mid<10^{\circ}$. Duże pulsacje prądów $i_{d}$ i $i_{q}$ w początkowej fazie przebiegów (do ok. 4 s) związane są z cykliczną generacją wektorów aktywnych napięcia falownika: $\underline{V}_{1}, \underline{V}_{3}, \underline{V}_{5}$, co jest wymagane przez algorytm przeznaczony dla małych prędkości wirnika.

Na rys. $4 b$ przedstawiono wyniki zarejestrowane podczas rozruchu silnika obciążonego mechaniczne znacznym momentem. Wpływ obciążenia na dokładność estymacji położenia nie jest widoczny. 


\section{Podsumowanie}

Zaproponowano i zaimplementowano estymatory położenia kątowego wirnika silnika IPMSM, w których estymacja wielkości mechanicznych jest realizowana poprzez analizę pochodnych prądów fazowych silnika związanych z modulacją napięcia wyjściowego falownika. Zaproponowane estymatory położenia kątowego wirnika poddano badaniom eksperymentalnym.

Regulacja momentu elektromagnetycznego trakcyjnego silnika PMSM wymaga dokładnej estymacji położenia $\mathrm{w}$ całym zakresie osiaganych prędkości. Wiąże się to $\mathrm{z}$ zastosowaniem zestawu metod estymacji przełączanych zależnie od prędkości kątowych wirnika.

Podczas opracowywania oraz badań metod estymacji uwzględniono przeznaczenie rozważanego układu napędowego do zastosowań trakcyjnych. Wykonano próby $\mathrm{w}$ szerokim zakresie prędkości kątowych wirnika, także w strefie odwzbudzania silnika. Uwzględniono konieczność realizacji rozruchu z dużym początkowym momentem obciążenia. Przebadano układ przy pracy $\mathrm{w}$ trybie hamowania odzyskowego oraz zmiany kierunku obrotów wirnika.

Algorytm estymacji wykorzystany dla małych prędkości wirnika odznaczał się stosunkowo dużymi wartościami błędów zarejestrowanymi podczas badań eksperymentalnych. Jest to spowodowane m.in. niedokładnym odwzorowaniem wykorzystanego silnika przez model przyjęty podczas opracowywania zależności matematycznych estymatora. Dodatkowo, wykorzystany silnik IPMSM cechował się małą różnicą indukcyjności $\mathrm{w}$ osiach $d$ i $q$ związanych $\mathrm{z}$ wirnikiem. W związku $\mathrm{z}$ tym duży wpływ na uzyskane wyniki miały niedokładności pomiarowe. Zastosowanie silnika o większej asymetrii magnetycznej byłoby wskazane zarówno $\mathrm{z}$ uwagi na zwiększenie dokładności estymacji jak również na podniesienie wartości momentu reluktancyjnego. Regularne występowanie określonej sekwencji napięć, wymagane przez algorytm estymacji, zrealizowano poprzez cykliczną modyfikację wartości zadanych modulatora napięcia. Powoduje to dość duże pulsacje w przebiegach prądów silnika, a co za tym idzie generację hałasu oraz strat, a także pogorszenie jakości sterowania. Dla uzyskania lepszych wyników konieczne jest dalsze udoskonalanie i strojenie metody fizykalnej.

Zaproponowane algorytmy odtwarzania wielkości mechanicznych poprzez analizę pochodnych prądów fazowych silnika charakteryzują się nieskomplikowanymi zależnościami matematycznymi. Niezależne wyniki estymacji otrzymywane są co jeden lub kilka okresów PWM, w zależności od metody. We wzorach nie występuje operacja całkowania. Trudność w implementacji estymatorów z proponowanej grupy wiąże się jednak ze złożonym, specyficznym algorytmem pomiaru prądów fazowych silnika. Pomiar musi być wykonywany częściej niż w przypadku układu czujnikowego, a chwile pomiaru muszą być skorelowane $\mathrm{z}$ przełączeniami tranzystorów falownika..

\section{LITERATURA}

[1] Bernatt J., Gawron S., Król E.: Nowoczesne silniki z magnesami trwatymi do zastosowań trakcyjnych, IX Międzynarodowa Konferencja „Nowoczesna Trakcja Elektryczna", Gdańsk (2009)

[2] Bianchi N., Bolognani S., Chalmers B. J.: Salient-Rotor PM Synchronous Motors for an Extended Flux-Weakening Operation Range, IEEE Transactions On Industry Applications, Vol. 36, No. 4, (2000), 1118-1125

[3] Bose B. K.: Modern Power Electronics and AC Drives, Prentice Hall PTR (2002)

[4] de Pablo S., Rey A. B., Herrero L. C., Ruiz J. M.: A simpler and faster method for SVM implementation, European Conference on Power Electronics and Applications (2007), $1-9$

[5] Jarzębowicz L.: Estimation of interior-permanent-magnetsynchronous-motor rotor position by analysis of phasecurrent derivatives, Electromotion (2010), Vol. 17, 15-22

[6] Jarzębowicz L.: Odtwarzanie położenia kątowego wirnika w silniku synchronicznym z magnesami trwatymi zagłębionymi $w$ wirniku poprzez analize pochodnych pradów fazowych, Przeglad Elektrotechniczny (4/2011), 264-269

[7] Jarzębowicz L.: Sterowanie trakcyjnym silnikiem synchronicznym z magnesami zagłębionymi $w$ wirniku bez pomiaru wielkości mechanicznych, Rozprawa doktorska, Politechnika Gdańska (2010)

[8] Kamonciak A.: Badania symulacyjne i eksperymentalne trakcyjnego układu napędowego z silnikiem IPM, Zastosowanie komputerów $w$ nauce $i$ technice, Zeszyty naukowe Wydziału Elektrotechniki $i$ Automatyki, Politechnika Gdańska (2004), nr 20, 97-102

[9] Ogasawara S., Matsuzawa T., Akagi H.: A PositionSensorless IPM Motor Drive System Using a Position Estimation Based on Magnetic Saliency, Electrical Engineering in Japan, Vol. 131, No. 2 (1999), 68-79

[10] Pochanke A.: Silniki bezzestykowe wzbudzane magnesem trwatym $w$ zastosowaniu do napędu pojazdów szynowych, Technika Transportu Szynowego (2008), nr 5-6, 22-25

[11] Schrödl M.; Simetzberger C.: Sensorless control of PM synchronous motors using a predictive current controller with integrated INFORM and EMF evaluation, Power Electronics and Motion Control Conference (2008), 2275 2282

[12] Tursini M., Petrella R., Parasiliti F.: Sensorless Control of an IPM Synchronous Motor for City-Scooter Applications, Industry Applications Conference, 2003. 38 $8^{\text {th }}$ IAS Annual Meeting. Conference Record of the. Volume 3, (2003), 1472-1479

[13] Wang Ch., Xu L.: A Novel Approach for Sensorless Control of PM Machines Down to Zero Speed Without Signal Injection or Special PWM Technique, IEEE Transactions on Power Electronics, Vol. 19, Issue 6 (2004), 1601-1607

[14] Zawirski K.: Sterowanie silnikiem synchronicznym o magnesach trwatych, Wyd. Politechniki Poznańskiej (2005) 